\title{
THE POST-APARTHEID XENOPHOBIC ATTACKS IN SOUTH AFRICA: A REFLECTION ON GOVERNMENT INTERFERENCES.
}

\author{
Anuoluwapo. A. Durokifa ${ }^{1}$ and E.O.C. ljeoma $^{2}$ \\ ${ }^{1}$ Department of public Administration \\ University of Fort Hare \\ 201316769@ufh.ac.za \\ ${ }^{2}$ Department of Public Administration \\ University of Fort Hare
}

\begin{abstract}
South Africa has witnessed series of xenophobic violence since the end of apartheid in 1994. The reoccurrence of these attacks has raised concerns in many quarters as to whether the Government has done enough to stop the attacks. Using a desktop methodology, the study unpacked Government response to the xenophobic attacks and tried to establish the various factors that may have contributed to xenophobic sentiments. The paper argues that the initiatives implemented by the Government not be effective in curbing the attack. It further argues that the South African Government may have indirectly contributed to the reoccurrence of these attacks on foreigners. The paper asserts that combatting xenophobic violence is more than merely altering or implementing a policy but requires addressing the fundamental basis that triggers conflict on which citizens lay their claim.
\end{abstract}

Keywords: South Africa; Xenophobia; Racism; Post-Apartheid; Immigrants.

\section{Introduction}

"I detest racialism, because I regard it as a barbaric thing, whether it comes from a black man or a white man"Nelson Mandela.

The above quote from the iconic liberation fighter and first democratically elected black president of South Africa do not appear to resonate with some sections of the South African population given the spate of xenophobic attacks that have rocked the country in recent years. This brings us to the question what xenophobia is?

Xenophobia is derived from the Greek words Xenos (foreign), and Phobos (fear or hatred or dislike). Hence, it literarily means hatred, dislike or fear of strangers (Chengu, 2015). For Petros. Airhihenbuwa, Simbayi, and Brown (2006:74), xenophobia is prejudice or an unjust treatment towards others because they are considered to be foreigners to the community, society or the national identity. Davis (2010) defines xenophobia as a highly negative perception and practice that discriminate against non-citizen groups by their foreign nationality or origin. In the South African context, xenophobia attack has/ does not only involve fear of citizens. It includes amongst other things: looting, destruction of properties, vandalism, hostility and abuse often leading to death especially towards blacks from

http://aps.journals.ac.za
African countries and in rare cases the Chinese, Somalians, Pakistanis, Bangladesh (HSRC, 2008:5). Implicitly, the contradictory act of South African towards foreigners' has been gruesome. This has earned South Africa notoriety as the hotspot of xenophobia in the world. According to Misago, Landau, and Monson (2008), since the country's liberation from apartheid, South Africa has been engulfed in a series of attacks that have claimed thousands of lives and property.

According to Human Rights Watch, South African's public culture had increasingly become xenophobic, and politicians often make unsubstantiated statements that immigrants are responsible for the current crime rate, rising unemployment and even the spread of diseases (Human Rights Watch, 1998:4).Chief Buthelezii is known to have made very disparaging remarks about foreigners which many believe may have fuelled the lust bout of xenophobic attacks. His suggestions that all Nigerian immigrants are criminals and drug traffickers appear to have been bought hook, line, and sinker by his subjects (NeoComos: 2008:588; Adjei and Lazaridis, 2014:238). However, this erroneous assertion has consistently been debunked by Nigerians. In an interview, Mike Enebechiii insisted that the framing of foreigners as criminals is wrong. Rather, there are lots of Nigerians who 
contribute to the economy of South Africa (Ashby and Diener, 2014:106).

Apparently, xenophobia and its attack on people have historical roots ${ }^{\text {iv }}$. Since 1994, foreign nationals have been offered rejection and denial of acceptance mostly because of their citizenshipv. "Makwerekwere"vi as they are often called has given some people ideological entrenchment at different times especially children in school who have received distinct behavior and anti-foreign sentiment (Bridger, 2015). Some people hold the view that the influx of foreigners into the country had led to an upsurge in the crime rate, drug abuse and drug trafficking, unemployment and other societal ills (Zuberi and Sibanda, 2004; Kingdon and Knight, 2007; Adeagbo, 20/3). Buthelezi in another standpoint proved to be one of those who believed the sweeping statement said of foreigners. In an announcement in August 1994, Buthelezi in explaining the unemployment state of South Africans to that of the foreigners within the country stated:

I am thinking of proposing to the cabinet, to consider legislation which will impose severe punishment on people who employ illegal citizens, as it is unpatriotic to employ them at the expense of our people..... It is really good for us to consider the wisdom in the saying that charity begins at home (Buthlezi 1994 in Croucher, 1998: 650-65I).

Even these sentiments are peddled by government officials, the deputy minister of home affairs, Ms. Lindiwe Sisulu, was reported to have said that foreigners were taking over jobs meant for South Africans. In a statement by her,

South African's immigration policy is premised on the thought that immigrant should not be employed at the detriment of a South African citizen.... (Sisulu, 1997).

Though all these attacks and incidences by the locals have been contrary to the underlying vision and statement of fathers of the land; such as Desmond Tutu and Late Nelson Mandela, who in their time envisaged and emphasized that "South Africa belongs to all who live in it, united in our diversity" (Matsinhe, $20 \mathrm{II}$ ). Also its epithet as a "rainbow nation" because it accommodates people from all over the world is regarded as an airy statement (Ashby and Diener, 2014: 2). Airy because of the unfounded link as parleyed above between foreigners and South Africans which in most times result to a violent attack on the former. However, many have risen against the xenophobia attacks. For instance, former South African President, Thabo Mbeki warned that

... it is fundamentally wrong and unacceptable that we should treat people who come to us as friends as though they are our enemies. We should not forget that the same people welcomed us to their countries when many of us went into exile as a result of the brutality of the apartheid system (Mbeki, 2001:303I).

Subsequently, other plea for accommodation and tolerance by the government, however, has not stopped the episodical act of violence (Crush and Ramachandran, 20I4). Hence, this paper relying on secondary literature and data will be analyzing the position of Government and steps they took in all these different times.

\section{SOUTH AFRICA, WHO ARE THE FOREIGNERS?}

Xenophobia is gotten from two Greek words Xenos (foreign), and Phobos (fear) means hatred, dislike or fear of strangers (Chengu, ibid). Boehnke et al., (1998) describes xenophobia as a behavioral sign of hostility against foreigners in society, expressed through the use of foul languages and violence. Though this term is not a new phenomenon ${ }^{\text {vii }}$; it has found its way to the center of government policy and concern considering the displacement, deaths, and damages attached to its outcome.

Xenophobic attacks have not shown any sign of abating in South Africa rather recent events seem to suggest that Xenophobic attacks, especially on fellow Africans, may be on the rise (Peberdy and Rogerson, 2002:39; McDonald, 2002:101-102). Research conducted by the Human Science Research Council (HSRC) between 1994-1995, attributes xenophobia towards African immigrants in South Africa to the period of democratization in the country in the 1990s (Minnar and Hough, 1996:26I; Crush, 200I). The coming of democracy led to the influx of people from Many African Countries into South Africa. A study carried out by South African Migration Project (SAMP) reveals that $40 \%$ of the South African population were opposed to African immigrants gaining access to social facilities in the country. $54 \%$ objected to the right to housing, $85 \%$ felt that illegal immigrants should be denied rights of free speech, freedom of movement and police protection (Crush, 200I). In a similar study, McDonald (ibid) observed the undesirable act of the citizens and their distaste for African foreigners to be a more opening for violence. According to Chengu (20I5), black immigrants are pejoratively perceived as foreigners, while whites are seen as tourists or expatriates. Not only that, whites are more likely seen as professionals and owners of companies. As Mngxitima (2008) puts it, xenophobia is the hatred of foreigners, but in 
South Africa, there are no white foreigners, just tourists, investors, and professionals, who live in quiet different and bigger cities like Cape Town. This explains the aggression and anger towards African immigrants because they are mainly seen as poor and in competition with locals. Thus creating platforms for attacks and perpetrations of violence in the country (Singer, 2000). These lewd acts have also taken a turn on some bonafide South African citizens because of their semblance (in skin color as too dark or in height or stature) like that of foreigners. Valj (2003) and Matsinhe (20II) in their study revealed that the police often make use of this bodily profiling to identify and detain suspected immigrants. Criteria which vary from skin color, dress style, language, height, hairdo, accent, smell or pronouncement of certain words has led to mistreatment of their own ${ }^{\text {viii }}$ just as they treat foreigners. These despicable acts forced The Congress of South African Trade Union (COSATU) to issue a statement which condemned the maltreatment of Africans:

....it is regretful that while hatred and oppression of fellow black South Africans have been shifted to the hatred of migrants from Africa. The Government, civil society formations and all organs of the state must prioritize the fighting of xenophobia. Like racism and tribalism, xenophobia must be defeated (Petkou, 2006: 173).

\section{THEORETICAL CONSTRUCT}

This study is premised on the theoretical construct of entitlement. In this construct, people are of the view that they are obliged to basic rights such as employment, housing medical care which cannot be shared with foreigners. This worldview is not unconnected with the many years of oppressive indoctrination where the colonial regime has come to frame foreigners especially Africans as interlopers and economic vermin (Chengu, 20I5). On how this could affect individualism, Franz Fanon ${ }^{\mathrm{ix}}$ argued that the ancient system of the white in chaperoning the black send messages that are so powerful and infiltrated their being. This made many black people succumb to these taunts and ultimately become defined by their mockery (Fanon, 1968).

Hence, the influx of foreigners and the competition for similar positions has puts the South African blacks in a threatening state and their resultant act (taking it on) on their fellow blacks. As Singer (2000) puts it, such actions were unleashed on the black during the apartheid era. Expectedly, competitions have ensued between citizens and foreigners for resources and opportunity, and as Fanon (ibid) puts it, the denial or shortchange of this possibility leads to the expression of aggression towards those who are in proximity to them. This acts which come in the form of violence ${ }^{x}$ have been attributed to a range of factors including criminality and most importantly the overpowering belief that the foreigners are taking their jobs due to the impoverished state of the Nationals (Friedman, 2008, NeoComos, 2010; AllAfrica, 2015). For instance, the majority of the xenophobic instigated incidents had occurred as a result of the local belief that the foreigners are taking over their job and women (see Table I).

Table I: Government Response towards Xenophobia in South Africa

\begin{tabular}{|c|c|c|}
\hline Date and Location & Description of Incident & Government Response \\
\hline $\begin{array}{l}\text { December } 1994 \text { to January } \\
\text { 1995. } \\
\text { Alexandra Township }\end{array}$ & $\begin{array}{l}\text { South Africans tried to evict "perceived } \\
\text { illegals" foreigners. Blaming them for increased } \\
\text { crime, sexual attack and unemployment in the } \\
\text { country. The campaign was known as } \\
\text { "Operation Buyelekhaya" (go back home) }\end{array}$ & $\begin{array}{l}\text { No Government response. } \\
\text { Though the ANC provincial } \\
\text { leadership condemned the act } \\
\text { and asked for the removal of } \\
\text { those who did not have } \\
\text { refugee status in the country. } \\
\text { The immigration act was also } \\
\text { altered after this incidence. }\end{array}$ \\
\hline $\begin{array}{l}\text { October and November } \\
1997\end{array}$ & $\begin{array}{l}\text { Local hawkers attacked foreign hawkers, } \\
\text { scattering and looting the foreigners' } \\
\text { belongings. In some cases, foreigners were } \\
\text { beating and stoned with sticks } \\
\text { There was a boycott and robbery on foreign } \\
\text { hawkers after a protest by the locals to chase } \\
\text { out the "makwerekwere" }\end{array}$ & No Government Response \\
\hline January 1998 & A Mozambican and two Senegalese were & No Government Response. \\
\hline
\end{tabular}




\begin{tabular}{|c|c|c|}
\hline Pretoria & $\begin{array}{l}\text { thrown out from a moving train by locals who } \\
\text { were coming from a rally that blamed } \\
\text { foreigners for unemployment, crime, and } \\
\text { spread of aids }\end{array}$ & $\begin{array}{l}\text { Though ANC condemned the } \\
\text { act. According to them, the } \\
\text { attack will create a perception } \\
\text { that South Africa do not } \\
\text { welcome foreigners in the } \\
\text { country (ANC Daily News, } \\
\text { 1998) }\end{array}$ \\
\hline $\begin{array}{l}\text { August, } 2000 \\
\text { Pretoria and Cape Flats }\end{array}$ & $\begin{array}{l}\text { Seven foreigners were killed in Cape Flat over } \\
\text { what the police regarded as motivation by the } \\
\text { fear that foreigners will want to claim } \\
\text { properties belonging to the locals. }\end{array}$ & $\begin{array}{l}\text { The then president, Thabo } \\
\text { Mbeki condemned the attack. } \\
\text { He sternly warned about the } \\
\text { abnormality in mistreating } \\
\text { foreigners who came to the } \\
\text { country as friends, like } \\
\text { enemies. }\end{array}$ \\
\hline $\begin{array}{l}\text { January, } 2008 \\
\text { Eastern Cape( Jefferys Bay } \\
\text { and East London) } \\
\text { March, } 2008 \\
\text { Atterridgeville, Pretoria } \\
\text { May, } 2008\end{array}$ & $\begin{array}{l}2 \text { Somali Shop owners were murdered } \\
\text { Seven people were killed including } \\
\text { Zimbabweans, Pakistanis and a Somalia after } \\
\text { their shop was lit on fire. } \\
\text { Locals attacked foreigners, looting and } \\
\text { destroying their homes, properties and } \\
\text { businesses. At least } 62 \text { people were killed, } 670 \\
\text { people wounded, dozens of women raped and } \\
\text { at least } 100000 \text { people were displaced }\end{array}$ & $\begin{array}{l}\text { This is the top xenophobic } \\
\text { violence that received } \\
\text { condemnation, not just from a } \\
\text { variety of organizations' and } \\
\text { leaders but also the rest of the } \\
\text { world. } \\
\text { The government saw the } \\
\text { attack as more of a criminal } \\
\text { and political issue. People in } \\
\text { relation to the attack were } \\
\text { arrested and convicted. Even } \\
\text { though the case was later } \\
\text { indirectly dismissed. }\end{array}$ \\
\hline $\begin{array}{l}\text { May, } 2013 \text { and } 2014 \\
\text { Pretoria and Port Elizabeth }\end{array}$ & $\begin{array}{l}\text { Four Somalis were killed. } \\
\text { In } 2014-\text { One Somali was stoned to death and } \\
\text { five foreigners injured }\end{array}$ & $\begin{array}{l}\text { The Government through the } \\
\text { foreign minister Maite } \\
\text { Nkoana-Mashabane } \\
\text { condemned the attack and } \\
\text { reassured its citizen and } \\
\text { Government of Somalia of the } \\
\text { safety of their citizens within } \\
\text { the country. However, this } \\
\text { reassurance did not change } \\
\text { anything as Somali citizens } \\
\text { were varyingly attacked in } \\
2014 \text { and } 2015 \text { respectively. }\end{array}$ \\
\hline $\begin{array}{l}\text { April 20I5 } \\
\text { Durban, Johannesburg, } \\
\text { CapeTown }\end{array}$ & $\begin{array}{l}\text { This horrifying attack has been causally linked } \\
\text { to the statements said by the Zulu King, King } \\
\text { Goodwill Zwelithini, and Edward Zuma. The } \\
\text { output of this occurrence led to the death of } \\
\text { I5 lives, displacement of over } 2000 \text { foreigners } \\
\text { and the loss of properties }\end{array}$ & $\begin{array}{l}\text { The government responded } \\
\text { by setting up refugee camps to } \\
\text { house displaced foreigners. It } \\
\text { also made use of the media in } \\
\text { campaigning for peace within } \\
\text { the country. }\end{array}$ \\
\hline
\end{tabular}

Source: Author's compilation (IOL, 2000; Crush, 2008; Lefko-Everett, 2008; Valji, 2008; Hayem, 20I3; Adjai and Lazaridis, 20I4; Gwala, 20I5; SAHO, 20I5).

Attesting to this, Allan and Hesse (2008) in their study, using a Municipal IQ, an index that is used to register protests and to evaluate the contributory factors, to affirm the underlining cause of violent amongst the poor. Their study shows that when the section of the poor evaluate themselves against their relatively better off fellow residents or foreigners, they blame the government for the failure to alleviate their conditions and breathes out their frustration. Such frustrations ${ }^{x i}$ bridge the pathway through which the social determinants of violence come to influence individual and group decisions resulting into 
aggression. Hence, the rash perception of foreigners as people who steal the National jobs, houses and women served as a trigger for public violence that assumed the xenophobic character (Moloefe, 2008). Each survival strategy adopted by a foreigner is seen as a threat to a National who perceives them as boycotting the social gains of post-apartheid in the country (See figure I).

Figure I: Theory of Entitlement

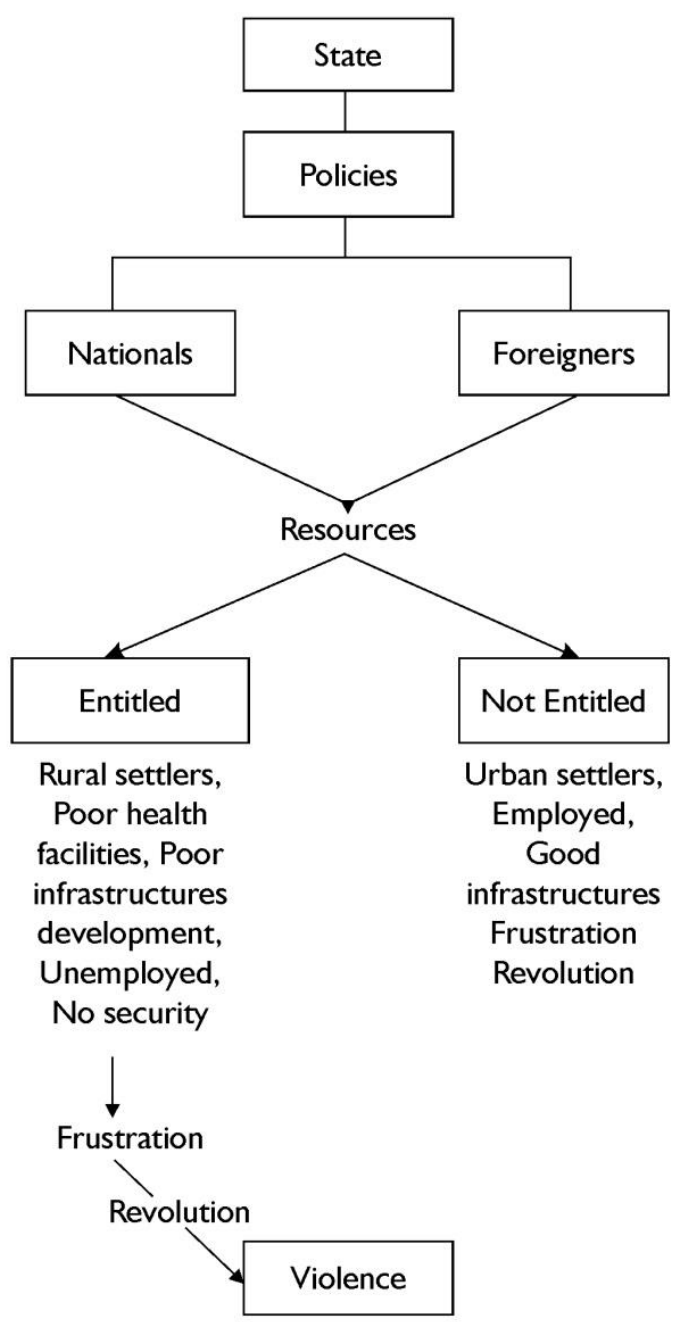

\section{BASIS FOR ANALYSIS-XENOPHOBIA ATTACKS IN SOUTH AFRICA}

Xenophobia in South Africa is a long-standing issue that had been in the country since the early 1990s. This discourse has resulted to varying xenophobic debates as to why South Africans should perpetrate violence against others, and also why they should not. Bridger (2015) attributed this indecent act exhibited by some Nationals to be the product of isolation faced by the Nationals during the apartheid era. According to her, students in schools are strategically shielded from the history and politics of other African states, propelling the hostile act towards foreigners. Researchers such as Higginson (2010) and Duncan (2012) in their study also attributes the xenophobic attacks within South Africa to the violent attitude of the people using the context of the 2008 xenophobic attacks. Both studies, attest that unanimity that black http://aps.journals.ac.za foreign nationals in South Africa face had been left unturn. For example, in 2006, South African Migration Project Survey [SAMP] found strong indications of xenophobia. In their study, half of the participants (50\%) favoured deportation of foreign nationals irrespective of their legal status, threequarter $(75 \%)$ was against increasing the number of refugees, and a similar proportion (75\%) favoured the idea of containing refugees in border camps, instead of being integrated into the society (SAMP, 2006). In 20I3, a similar survey was administered by SAMP, and their findings recorded that $50 \%$ of South Africans wanted foreigners to have their identity documents on them all the time, $63 \%$ would like to have the country's border electrified, $50 \%$ favoured migrants without proper documentation be denied police protection; $30 \%$ wanted a complete ban of immigrants into the country. $14 \%$ thought all migrants are coming into South Africa, comes in to 3297 
perpetrate crime (SAMP, 20I3). These SAMP findings demonstrated consistency in the negative attitude nationals has towards foreigners especially fellow blacks from African countries.

It is to note that these episodic acts of violence are based on the long-simmering anti-migrant ${ }^{\mathrm{xii}}$ sentiments that have been brewing in the country since the liberation movement of 1994. Foreigners are the transferred aggression recipients blamed for the country's malfunction such as high crime rate, disease, and unemployment. These three has been a basis for a sporadic attack on foreigners and resulted into series of destructions, deaths, and displacement. Considering this litany of incidence against foreigners, one cannot but peruse the role of Government in these attacks. Since most research conducted on xenophobia focused on the poor treatment of foreign nationals in South Africa and their consequences (Crush, 200I; NeoComos, 2008; Duncan, 20I2).

\section{Xenophobia in the South African Context}

Xenophobic attacks in South Africa started in 1994 and had since then sprung up reactions from the Government. In 1994, armed residents of Alexandra ${ }^{\text {xii }}$ engaged in "Operation Buyelekhaya" (Go back home) which entails evicting people whom they perceived to be illegals ${ }^{\text {xiv }}$ living within the township. They were blamed for the increase in crime rate, sexual attacks, and unemployment. This turn of event prompted the then president, late Nelson Mandela who in recognition of the violence caused stated in his speech to the parliament....

We are all aware of the tensions that are building up about population movements. We must treat this matter with all due sensitivity, conscious of the history of our region, including the destruction caused by the policy of aggression and destabilization of carried out by the previous regime. In all our actions, we must move from the position that fundamental objective we must pursue friendship, cooperation, and solidarity among the people of our region (Mandela, 1995).

However, the president's speech and the amendment to the immigration law ${ }^{\mathrm{xv}}$ did not deter the barbaric act. In August 1997, local hawkers in Central Johannesburg attacked their foreign counterparts for two consecutive days, scattering, looting and beating their foreign counterparts. Another incident broke out in 1998 when a Mozambican and two Senegalese were thrown out of a moving train. This assault was carried out by a group that was coming from a rally that blamed foreigners for their unemployment, crime and the spread of AIDs (Valji, 2008, Adjai and Lazaridis, 2014:246). In 2000, seven foreigners were killed in Cape Flat over what police described as xenophobic 3298 murder possibly motivated by fear of foreign nationals claiming the property that belong to the Nationals (IOL, 2000). A Sudanese refugee was also thrown from a train by a group of armed men in Pretoria (Lefko-Everett, 2008: 30). The year 200I, also welcomed another attack between the locals of the informal Handprint settlement and the Zimbabweans on the failure of the Zimbabweans to leave the area as directed by the locals. Turns of these events prompted Thabo Mbeki appeal to South Africans on the Annual celebration of African Day to be watchful against racism and xenophobia (Mbeki, 200I). However, the notorious attacks that attracted international condemnation were the xenophobic events of 2008.

The violence started on IIth May from the township of Alexandra and spread through to other townships in other provinces. By $30^{\text {th }}$ May when the attack finally ceased, there was a death toll of 62 people, including 21 South Africans, 670 people wounded, dozens of women raped, at least 100000 people displaced and property worth millions of rands looted (Amisi et al., 20II). While condemning this attack on people, the Government, however, insisted that the incidents were not xenophobic, nor an internal, social or political crisis. Instead, the government chose to see the situation as a criminal issue (Crush, 2008:38; Mbeki, 2008; Hayem, 2013:87). A statement by the then Minister of Safety and Security, Charles Nqakula, initially responding to the attacks in Alexandra said: "it is only a problem, but if it were a crisis, it would be happening right across the country." However, the spread of this attack to other parts of the country did not generate statement from the government to dissuade the situation. Many describe this policy of silence to be a tactical way of chasing away the foreigners and a subtle way of governmental approval (Duncan, 20I2). Also, the government promised to create a special court for 1400 accused $^{\mathrm{xvi}}$ and arrested during this violence attack but their failure to do so weakened the Government condemnation of the attack.

According to a study conducted by African Centre for Migration and Society, their findings showed that at least one foreigner each month falls under delirious attacks since 2008 (Magubane, 20I5). In both 2013 and 2014, there were brutal attacks ${ }^{\text {xvii }}$ on the Somalia Nationals. In 2015 $5^{\text {xiii }}$ there was another round of xenophobic attacks on foreigners similar to that of the 2008 event. This event claimed 15 lives, led to 307 arrests and the displacement of over 2000 foreigners in the Republic (Gwala, 20I5; SAHO, 20I5). In all these attacks, there are three emerging trends or existing commonalities that had been fundamental basis. They are social vices, service delivery, and competition for jobs.

http://aps.journals.ac.za 


\section{Competition for Job}

Job competition, in general, is a contest between two or more individuals, economic group or social group for resources, profit or a sustainable livelihood. Competitions mostly occur between people who live in the same environment (Keddy, 200I). The motivation for job competition happens when people strive for a particular need which they believe cannot be shared. Instead, it is their absolute right. For the purpose of this study, job competition here is between the foreigners and the locals.

The phrase "migrants had taken over our jobs" has been an oft-quoted phrase and a basis for violence attack exhibited by indigenes especially those in the informal sector ${ }^{\text {xix }}$ (The Star, 1997; Human Rights Watch, 1998; Zuberi and Sibanda, 2004). A study conducted by Crush (200I: 125) revealed that $61 \%$ of his respondents believe that immigrants place a strain on their economy because of their employment rate. Also, Dodson and Oelfose (2000) and Misago et al. (2009) in separate studies ascertained that the competition for the job is one of the main factors driving hostility between indigenes and foreigners. Implicit in this assumption, is that South African nationals are the only ones entitled to employment in the country and foreigners are depriving them of the opportunity.

However, a study by Migrating for Work Research Consortium $^{\mathrm{xx}}$ (MIWORC) using a labour data collected in the year 2012 proves that $80 \%$ of the working population between the ages of 15-64 years are non-migrants, $14 \%$ are domestic migrants that had moved between provinces in the last 5 years, and $4 \%$ could be classified as foreign migrants (Wilkinson, 2015). Out of a working population of 33017579 , this $4 \%$ constitute 1.2 million people (Thlabi, 20I5; Wilkinson, ibid). This posits that international migrants have high unemployment rates, unlike other countries in the world where international migrants are given top consideration when it comes to employment opportunity (Wilkinson, ibid).

Also, the Labour Act on Migrants policy also places the control on the job for foreigners. The act affirms that foreigners should not be given jobs at the expense of South Africans except if there is no citizen to do the job (Sisulu, 1997). Therefore, the policy has led most foreigners who are much qualified for formal jobs into unstable unemployment where they do not have access to benefits or full employment grant. While some had resorted into running their own business in the informal sector because of the low cost they are offered, some of these employers, on the other hand, like to employ foreigners. In an interview excerpt, a man who resides in Cape Town revealed the reason why most employers prefer hiring foreigners. According to him,
"The reason why many employers employ foreigners is that their English is good, and they have the ability to interact well with customers. Also, they are good in other skills like literacy and numeracy, and they are paid less" (Business Day Live, 2015). In light of all this, the widespread belief that the presence of foreigners deprives the indigenes of their livelihood has been proved on the contrary. Evidence by Peberdy ${ }^{x i}$ (Wilkinson, 2015), suggests that foreign nationals contribute to South African economic development by providing jobs, payment of VAT, payment of rent and providing affordable and expedient goods. Their study found that out of 618 foreign traders interviewed, $31 \%$ rented properties from South Africans. Also, out of 1223 employed in total by foreigners, 503 people are South Africans. Another interview excerpt by a foreigner who has a restaurant in Cape Town faults the notion that foreign nationals steal their jobs. In his words,

...Pretty much, all our employees are local except for two Zimbabweans and one Congolese out of 20 people (Business Day Live, 2015).

The presence of foreigner's business (spaza shop) especially with those in the township or informal settlement where inequality is high mostly triggers frustration, fear, and inferiority complex which in turn lead to an attack on these foreigners (Fanon, 1968; Vahed and Desai, 2013). Herewith, it can be asserted that there is a disconnection between the perceptions of the indigenes and the reality of what exactly goes on in the country.

\subsubsection{Social Vices}

...Alien ${ }^{\text {xxii }}$ has become a swearword in this country used by xenophobes who have come to take over our jobs, our women; our homes and feed us drugs" (The Star, 1995 cited in Harris, 2002: 178).

The assumption of this nature has become commonplace in the identification of a foreigner. This has led to stereotypes of foreign nationals in South Africa. A majority of South Africans believe that foreigners are crime perpetrators and carrier of diseases such as HIV/AIDS (Chirwa, 1998; Human Rights Watch, 1998:4). These statements often portray foreigners as a threat to the socio-economic stability of the State. For instance, in an unsubstantiated claim made by the former Senior Police Superintendent, Johan Steyn, $90 \%$ of criminals who break into homes, commit armed robbery and rape women are Zimbabweans (Murray, 2003). However, research that investigated all the arrests carried out in 1998 showed that $98 \%$ of those arrested are South Africans (Harris, 2001:76). Similarly, a report by the National Institute for Crime Prevention and the Reintegration of Offenders indicates that in 2014 , only $4 \%$ of II 2,467 sentenced 
prisoners are foreigners puncturing the stereotype of all foreigners as criminals (Wagner, 2014).

The media has also exacerbated xenophobia by portraying certain Nationals with specific crimes. For instance, Nigerian immigrants are associated with drug trafficking and money laundering; Zimbabweans have been attributed with housebreakings, Mozambicans with Gun running and the Congolese with passport racketeering, Lesotho Nationals with smuggling of gold dust and cooper wire (Legget, 1999; Danso and McDonald, 200I).These inflammatory and wide generalizations have been used for the basis of committing social vices, criminality and xenophobic attacks in South Africa not minding that some foreigners are also victims of this crime. Another major but false factor that has emerged as a trend in this discuss has been that foreign nationals have become the major recipient of service delivery.

\section{Service Delivery}

From the above assertions, Legget, 1999; Danso and McDonald, 200I; Murray, 2003 tend to argue that foreigners have more privilege to locals in the distribution of services and amenities in communities. Hence, the locals assume that the allocation of service delivery to foreigners is illicit (Van Holdt, 2010). Foreigners have been labeled as 'illegitimately accessible' to the economic goods, facilities, and rights, which are expressly South Africans entitled. Scrutinizing data on the xenophobia attack of May 2008, one main motive for the brutalization and looting of foreigners' shops, offices, and homes are the belief that foreigners compete with citizens over their rightful resources. A focused group discussion organized by South African Women in Dialogue (SAWD) with Alexandra women in July 2008, argues that "foreigners are violating their Human Rights". Similarly, an interview conducted by Forced Migration Studies Programme [FMSP] ${ }^{x \text { iii }}$ in July 2008, deduced that foreigners are getting more entitlement from the government. In an excerpt from a Tembisa resident:

This area is tired of foreigners and they seem to be receiving from our government more than us, some of them have houses, we don't.

This may explain the reason for Buthelezi's outrageous statement in 1994

I am thinking of proposing to the cabinet to consider legislation that will unleash severe obstruct and not share their practices with local business owners (Magubane, 2015). Also, the king of Zululand, King Goodwill Zwelithini and Edward Zuma in separate gatherings urged foreigners to leave the country (News 24, 20I5; All Africa, 20I5). punishment to people who employ foreigners at the expense of our people. It is splendid for us to consider the wisdom saying that charity begins at home (Buthlezi, 1994 cited in Croucher, 1998:650-I)

However, against this sweeping beliefs, Sebola (2008) and Managa (20/2) argues that foreigners living in claimed Reconstruction and Development Programme [RDP] houses bought them. Ironically in most cases, these houses are bought from political elites or citizens who want to enrich themselves with the state resources. Also, foreigners are not eligible to specific service delivery that the government executes. Such as the welfare grants, employment in some locations, amongst others.

Thus, as noted by Danso and McDonald (200|:|32-|33), citizens are often fed or feign incriminating innuendos, notions, assumption, and sensational assertions on what foreigners are alleged to have done giving credence for xenophobic attacks in the country.

Government Interventions in Xenophobia Attacks. The 1995 Freedom Charter drafted by the ANC and its allies stated that South Africa belongs to all those who live in it. However, this statement has been reconstrued with series of xenophobic attacks on foreigners by the locals within the country. As noted by Prince El- Hassan (200I:I-2), no society is immune to xenophobia. The ability of the government to curtail it is what is important. For South Africa, many studies seem to hold that government has not shown enough concern to the issue of attacks on foreigners within the country (NeoComos, 2010; Hayem, 2013, Bernardo, 20I5). Government attitude towards an attack on foreigners has been regarded as incoherent, inconsistent and contradictory. Most Government officials have been accused of fueling the tension between foreigners and the citizens through unguarded and reckless statements. For instance, weeks preceding the 2015 xenophobic attack, Nomvula Mokonyane ${ }^{\text {xxiv }}$ posted on his Facebook timeline a contradictory statement: In Kagiso, almost every shop outlet (spaza) or former general dealer shops are run by the Somali or Pakistan... I am not xenophobic comrades and friends, but this is a recipe for disaster (Wilkinson, 20I5). In a similar statement, Lindiwe Zulu stated that Foreigners need to understand they are here as a curtsy, and our priority is to the people of the country first and foremost... They cannot come and These statements are said to have acted as underground basis and drive of the scuffle between the foreigners and locals in the 2015 xenophobic attacks. 
Although the governments have made series of statements condemning the acts, there has been no equitable judgment carried out. For instance, Thabo Mbeki's statement after the 2008 xenophobia However, after each xenophobic attack, the government comes up with new regulations in tightening the immigration laws ${ }^{\mathrm{x} v \mathrm{v}}$ ostensibly to reduce the flow of foreigners into the country (Adjai and Lazaridis, 20I3, Gigaba 20I4). This seems to suggest that the government agree with its citizens that there are loopholes in the immigration policy which foreigners exploit to come to South Africa. It indirectly supports that foreigners are responsible for the lack and poverty its citizens are experiencing.

The government had also assisted in rendering palliative measures to foreigners and citizens displaced during the crisis by building temporary refugee camps ${ }^{\text {xxvi }}$ and providing food and other necessities. The government also as part of its palliative measures sets up security agencies such as the National Joint Operation Centre (NATJOC) and the Provincial Joint Operation Structure (PROVJOCS) to monitor and curb potential threats that might want to come up in any of the nine provinces. It had also arrested and convicted citizens who were in connection with attacks on foreigners. In most cases, however, the cases were dismissed due to lack of witnesses or the absence of suspects (Monson and Misago, ibid).

Rhetoric is another technique the Government uses in calming the xenophobic tension within the country. The Government had utilized the media in propagating peace, and the "all is well" slogan within the country, even when some South African citizens, and Government officials are in contradiction. The government regards xenophobic attacks as 'shameful,' 'blemish' and disrespect to human rights and the enshrined constitution. It has also internalized the media as a source of campaign and awareness in educating the citizens on the contributory role African and other foreign countries played towards the liberation of the country during apartheid (McDonald et al., 1998; Handmaker and Parsley, 2002; Hayem, 2013). For instance, on May 25,2008 , in a statement to curb the xenophobic violence brewing, Mbeki declared We must never forget that our economy was built by the combined labor of African drawn from all countries of our region, many of whom died in our mines together with their fellow South African workers. Neither should we forget, that many people from other African countries helped to build our liberation movement. While many in our region died because of apartheid aggression as they supported us in the struggle to defeat apartheid (Mbeki, 2008). incidence followed by the assertiveness of carrying out justice went under the carpet due to pressure from traditional and political leaders and the local communities (Monson and Misago, ibid).

Additionally, there is the media propaganda and ethnic profiling. The government has not officially stated the role foreign labor and their presence plays in the economy of the country. Rather, it has given room for the media to propagate xenophobic statements indirectly. For instance, the Minister of Housing announced that the escalating house shortage in the Country is caused by foreigners (Maharaj, 2004:9-II). The press has also promoted the labeling of foreign nationals from African as job stealers, criminals, and illegals, and on the other hand highlighted foreigners from Europe and other western countries in a positive light (Danso and McDonald, 200I; McDonald \& Jacobs 2005:5). In furtherance of government interventions, Table I demonstrated different ways which the Government intervened in each varying attack that took place within the country.

\section{CONCLUSION}

By and large, the interventions of South African Government have not been successful. The South African Government response towards xenophobic attack has been more of grandstanding and political posturing to suit South African citizens. This had been evidenced in varying subsequent xenophobic violence that had taken place irrespective of reforms and policy that had been altered and implemented. Clearly, going from the testimonials above, the government had played a contributory role in the unhealthy environment between the locals and the citizenry making a considerable percentage of South Africans ignorant of foreigners experiences in the country.

Going forward, there is a need for the South African Government, and the foreign office in particular to dialogue with its citizens and holistically examine the complaints made by its citizens. The Government seems to gloss over the issue that the citizens are not attacking foreigners because they are foreigners rather they feel foreigners are depriving them of certain essential necessities of life. Xenophobia is not an issue of criminality and immigration; neither can it be resolved through policing and immigration policy reforms. The surrounding issue mostly has to do with the misreading of differences. The argument that foreigners are responsible for their poverty, inadequate service delivery, and general lack has not been clearly debunked. Although, one major flaw of this study is its inability to interpret and ask diverse questions as" why are lawful foreigners doing better? 
Why do South African citizens still work for foreigners if they see them as a threat to their economy or country? Questions of this nature are quintessential if the stands of locals in the communities must be uplifted and if Government will want to stop xenophobia attack.

\section{REFRENCES}

Adeagbo, O.A., 2013 'We are not criminals; we are just victims of circumstances': An Exploration of experiences of Nigerian immigrants' Men that married South African Women in Johannesburg. National Identities, I5(3), pp.277-296.

Adjai, C. and Lazaridis, G., 2014. People, State and Civic Responses to Immigration, Xenophobia and Racism in the New South Africa. Journal of International Migration \& Integration, 15(2), pp.237-255.

All Africa., 2015. South Africa: Shirdon Calls On South Africa to Protect Somali Nationals. [Online] I8 March. Available at: allafrica.com

Allan, K. \& Heese, K., 2008. Service delivery failures and xenophobic attacks. Business Day,

p. 13, 20 May.

ANC Daily News Briefing, 1998. ANC Briefing Statement on the killing of Foreigners. $4^{\text {th }}$ September [Online] Available at: http://209.85.229. I 32/search?q= cache:g I LtFrujX 8]:www.anc.org.za/show.php\%3Fdoc\%3Dancdoc s/pr/l 998/pr0904b.html+train +\%224+septemb $\mathrm{er}+1998 \% 22 \& \mathrm{~cd}=|\& \mathrm{hl}=\mathrm{en} \& \mathrm{ct}=\mathrm{clnk} \& \mathrm{~g}|=\mathrm{za}$

(http://209.85.229.132/search?q= cache:g I LtFr24/ uiX8]:www.anc.org.za/show.php\%3Fdoc\%3Danc docs/pr/1998/pr0904b.html+train+\%224+septe $\underline{\mathrm{mber}}+|998 \% 22 \& \mathrm{~cd}=| \& \mathrm{~h}|=\mathrm{en} \& \mathrm{ct}=\mathrm{clnk} \& \mathrm{~g}|=\mathrm{za}$ \{Accessed 28 August 2016\}

Ashby, D.J., and Diener, W., 2014. Exploring the Dynamics between Discrimination and Identification amongst Nigerian Immigrants in Durban, South Africa. Thesis. Aalborg University.

Bridger, E., 2015. Xenophobia in South Africa, Historical Legacies of Exclusion and Violence. $\mathrm{CIGH}$ Exeter [Online] May 6. Available at: https://imperialglobalexeter.com/2015/05/06/xeno phobiainsouthafricahistoricallegaciesofexclusionan dviolence/ \{Accessed 28 August 2016\}.

Chengu, G., 2015. Xenophobia in South Africa: The Apartheid Legacy of Racism and White Corporate Capitalism. Global Research [Online] Available at: www.globalresearch.ca/xenophobia-in-southafrica-the-apartheid-legacy-of-racism-and-whitecorporate-capitalism/5443965 \{Accessed 24 August 2016\}

Cox, A., 1995. Armed Gangs Force Foreigners out of their Alexandra homes. Star, January 25.
Crush, J., \& Williams, V., 200I. The South African White Paper on International Migration: an analysis and critique. Cape Town: SAMP IDASA.

Crush, J. \& Ramachandran, S., 20I4. Xenophobic violence in South Africa: denialism, Minimalism, realism. Southern African Migration Programme (SAMP). International Migration Research Centre (IMRC). Migration series no 66 [Online] Available at:

http://www.queensu.ca/samp/sampresources/sam ppublications/policyseries/Acrobat66.pdf \{Accessed 9 February 2017\}

Croucher, S., 1998. South Africa's illegal aliens: Constructing National Boundaries in a PostApartheid state. Ethnic and Racial Studies, 2I(4), pp. 639-660.

Danso, R., and McDonald, D. A., 200I. Writing Xenophobia: Immigration and the Print Media in Post-Apartheid, South Africa. Africa Today, 48(3), II5-137.

Dodson, B and Oelofse.C., 2000. Shades of xenophobia: In-Migrants and Immigrants in Mizamoyethu Cape Town, Canadian Journal of African Studies / Revue Canadienne des EtudesAfricaines, (34), pp. 125-I48.

Fanon, F., 1968. The Wretched of the Earth. Harmondsworth: Penguin.

Gigaba, M., 20I4. South African tightens Immigration Rules. [Online] 2 June. Available at: http://www.southafrica.info/travel/immigration020 6I4.htm\#.V9KNa krLIU \{Accessed 9 September 2016\}.

Gwala, X., 2015. Xenophobia: How South Africa Got Here. [Online] 16 April. Available at: http://www.702.co.za/articles/2500/xenophobiaho wsouthafricagothere $\{$ Accessed 30 August 2016\}

Harris, B., 200I. A Foreign Experience: Violence, Crime and Xenophobia during South Africa's Transition, Centre for the Study of Violence and Reconciliation (CSVR), Violence and Transition Series [Online] Vol 5, August. Available at: http://www.csvr.org.za/papers/papvtp5.htm

\{Accessed 24 August 2016\}

Harris, B., 2002. Xenophobia: A new pathology for a New South Africa. In: D. Hook \& G.Eagle (eds.) Psychopathology and Social Prejudice. Cape Town: University of Cape Town Press, pp.169184

Hayem, J., 2013. From May 2008 to 201I: Xenophobic Violence and National Subjectivity in South Africa, Journal of Southern Africa Studies, 39 (I), pp. 77-97. DOI:I0.1080/03057070.2013.767538.

Human Rights Watch, 1998. Prohibited persons: abuse of undocumented migrants, asylum seekers, 
and refugees in South Africa. New York: Human Rights Watch.

IOL, 2000. Xenophobic attacks: Seven die in One Month. [Online] Available at: http://www.iol.co.za/news/southafrica/xenophobic-attacks-seven-die-in-onemonth-45733 \{Accessed 28 August 2016\}.

Kingdon, G. \& Knight, J. (2007) Unemployment in South Africa, 1995-2003: Causes, Problems and Policies. Journal of African Economies, 16(5), pp.8|3-848.

Landau, L., 2008. Attacks on foreigners in South Africa: More than just Xenophobia?

LefkoEverett, K., 2008. Aliens, Migrants, Refugees and Interlopers: Perceptions of Foreigners in South Africa. EPoliticsSA, ed. I. [Online]. Available at:

http://www.idasa.org.za/index.asp?page=output details.asp\%3FRID\%3D I554\%26oplang\%3Den \%26OTID\%3D5\%26PID\%3D44 Accessed 8 September, 2016\}.

Magubane,K., 2015. Reveal Trade Secrets, Minister tells Foreigners. Business Daily Live. [Online] 28 January. Available at: www.bdlive.co.za/national/2015/0I/28/revealtrade-secrets-minister-tells-foreigners $\{$ Accessed 9 September 2016\}.

Maharaj, B., 2004. Global Migration Perspectives No.I. Global Commission on International Migration. Geneva, Switzerland.

Managa, A., 2012. Unfulfilled Promise and Their consequences: A reflection on local government performance and the critical issue of poor service delivery in South Africa. Africa Institute of South Africa. Briefing Policy No 76.

Matsinhe, D.M. (20I la) Africa's Fear of Itself: the ideology of Makwerekwere in South Africa. Third World Quarterly, 32(2), pp.295-3I 3.

Mbeki, T., 200I. Letter from the President, Our commitment to Africa. ANC Today, I(I8), pp.2531.

McDonald, D.A. and Jacobs, S., 2005. Understanding Press Coverage of Cross-Border Migration in Southern Africa since 2000. Southern African Migration project.

Misago, J.P., Landau, L., and Monson, T., 2009.Towards Tolerance, Law and Dignity: Addressing Violence against Foreign Nationals in South Africa.

Misago, J.P., Landau, L.B. \& Monson, T. 2008. Tensions, Territory and Terror: Understanding Violence Against Foreigners in South Africa. University of Witwaterstrand.

Mngxitama, A.,2008. Minds of South Africans need to be decolonized. City Press, p. 26, 18 May
Molefe, T., 2008. Alexandra—a slow-burning fuse set to explode. Sowetan, p I3, 15 May.

Monson, T and Misago, J.P., 2009. Why History Repeated Itself. The Security of Structural Xenophobia. SA Crime Quarterly, 29.

Murray, M.J., 2003. Alien strangers in our midst: The dreaded foreign invasion and "fortress South Africa". Canadian Journal of African Studies / Revue Canadienne Des Études Africaines 37 (2/3), pp. 440-466.

NeoComos, M., 2008. The Politics of Fear and the Fear of Politics: Reflections on Xenophobic Violence in South Africa. Journal of Asian and African Studies, 43(6), pp.586-594.

NeoComos, M., 2010. 'From Foreign Natives to Native foreigners' Explaining Xenophobia in PostApartheid South Africa. CODESRIA, Dakar.

News24, 2015.Zuma's Son wants Foreigners out of the Country. [Online]I April. Available at: http://mg.co.za/article/20 I5-04-0I-zumas-sonwants-foreigners-out-of-the-country \{Accessed 7 September 2016\}.

Peberdy, S., 200I. Imagining Immigration: Inclusive Identities and Exclusive policies in Post 1994, South Africa. Africa Today, 48(3), 15-33.

Sebola, M., 2008. Managing the provision of low cost housing in South Africa: Evaluating the access to habitable housing and the migration impact on housing delivery. South African Association of Public Administration and Management. Conference Proceedings.

Sisulu, L., 1997. Media Release by the Deputy Minister of Home Affairs, 19 August 1997.

Thlabi, R., 2015. How many Foreigners are Working in South Africa. Far Fewer than You think? [Online] 22 April. Available at: www.702.co.za/articles/2569/how-manyforeigners-are-working-in-south-africa-far-fewer than-you-think \{Accessed 7 September 2016

Valji, N., 2003. Creating the nation: the rise of violent xenophobia in the New South Africa. Unpublished Masters Thesis. York University. [Online] Available

at: http://www.csvr.org.za/docs/foreigners/riseofviole nt.pdf $\{$ Accessed 8 September 2016\}.

Valji, N., 2008.Creating the Nation: The Rise of Violent Xenophobia in the New South Africa. Centre for the Study of Violence and Reconciliation (CSVR), Violence and Transition Series.

Wagner, L, 2014. Crime Wave Not Due to Foreigners, SA Jail Figures Show. Business Day Live. [Online] April 9. Available at: www.bdlive.co.za/national//014/04/09/crimewave-not-due-to-foreigners-sa-jail-figures. \{Accessed 7 September 2016\} 
Wilkinson, K., 20I5. ANALYSIS: Are Foreign Nationals Stealing Our Jobs in South Africa? Mail and Guardian [Online] 17 April. Available at: mg.co.za/article/20l5-04- I 7-analysis-areforeigners-stealing-jobs-in-south-africa. \{Accessed 9 September, 2016\}

Zuberi, T. \& Sibanda, A. (2004) How Do Migrants Fare in a Post-Apartheid South African Labour

' Foreigners here refer to people from other parts of Africa.

ii Buthlezi was the first minister of home affairs (19942002) and leader of the Zulu-based Inkatha Freedom Party

iii Mr, Mike Enebechi is the Chairperson of the Kwazulu Natal Nigeria Union of South Africa

iv Serious attack on Non South-Africans took place in the Alexandra Township near Johannesburg. For several weeks, South Africans tried violently to evict perceived "illegals" from the towns blaming them for the increase in crime rate, economic deprivation and unemployment (Cox, 1995)

${ }^{\vee}$ Citizenship here connotes foreigners who do not have South African land blood flowing within them. Even South African citizens by naturalization are regarded to be foreigners.

vi Makwerekwere described in Mpe's novel "Welcome to our Hillbrow" is derived from Kwere Kwere, a sound that unintelligible foreigners make according to locals (Mpe, 200I:20)

vii Xenophobia reports were reported in Germany, Switzerland. Britain, Russia (Boehnke, et al., 1998; Ford,
Market? International Migration Review, 38(4), pp. |462-|49|.

SAHO, 20I5. [Online] Available at: http://www.sahistory.org.za/article/xenophobicviolence-democratic-south-africa Accessed 2 September, 2016\}.

1992; Weiner, 1995).For instance, In Germany, the importance of foreign workers were stopped in 1973 leading to an increase in the number of applications for asylum (Weiner, 1995). Also in Kenya, there was report on the attack of Sudanese refugees for perpetrating supposed crime and transmitting diseases (Crisp, 2000). The xenophobic attack in South Africa has also been documented.

viii Bonafide South African citizens

ix Franz Fanon was a psychology expert on colonial violence

${ }^{x}$ Xenophobic attacks

${ }^{x i}$ This frustration gains substance and form when an event or series of event whether real or imagined instigates the tipping point.

xii The belief that xenophobia in South Africa stated in 1998 when a mob of South Africans attacked and killed foreigners for allegedly taking away their job is out rightly contended. According to Crush (200I:II), a research report by SAMP in 1995 revealed a large amount of hostility showed towards foreign migrants. Also, a study conducted by HSRC between 1994 and 1995 unveiled negative sentiments towards foreigners (Minnar and http://aps.journals.ac.za 
Hough, ibid). Hence, it won't be wrong to contend that xenophobia had been in the country after the period of democratization in the early 1990s when South Africa opened its door to the rest of the world.

xiii Alexandra is a well-established township close to Johannesburg. It has a history of sheltering migrants and immigrants. It is also well known as a strong hold of civic activism and radical democratic politics (Holder, 2012:34).

xiv Illegals here are particularly people from Zimbabwe, Mozambique and Malawi (A. M innaar and M. Hough, Who goes There? Perspective on Clandestine Migration and Illegal Aliens in Southern Africa \{Pretoria: Human Sciences Research Council, 1996\} 188.

${ }^{x v}$ Amendment was made from the 1991 Aliens Control Act to the Alien Control Amendment Act No 76 of 1995. The act overridden was considered too soft on grounds that it did not provide sufficient control for government. Speaking on the amendment Act, the Deputy Minister of Home Affair stated the purpose of the amendment act was to implore control over immigration ( Crush and McDonald, 2002:6; Adjai and Lazaridis, 2014:242).

xvi The Director of Public Prosecution has said in June that he planned to carry on the case with the 1400 people accused with the violence attack of May 2008. Instead, many suspects were released under pressure from the community, political leaders and families (see Monson and Misago, 2009).

xvii On $30^{\text {th }}$ May, 2013, a Somalia man was stoned to death. In the same year, three Somali shopkeepers were killed. In June 2014, there was another attack, A Somalia shop was mobbed and a man in his 50 s was stoned to death, two others were seriously injured and three more Somalis were wounded from gunshots. ( see All Africa, March 18 2015; World Bulletin, June 9 2014)

xviii January 2015, a Somali shop owner and a 14 year old boy were shot during an alleged robbery in Soweto. This incident triggered waves of attacks to the foreigners and looting of foreign shops. Documented 120 shops were totaled to be looted. On March 5 2015, foreigners residing in the outskirts of Polokwane left their shops in number owing to the threat by the locals to burn them alive and then loot them and in Sekgopo, foreigners were pushed out of II villages. The one which however sparked up flames was the statement made by Zulu King GoodWill Zwelthini that foreigners should go back to their home countries because they are changing their society. This statement contributed to the xenophobic sentiments expressed by South Africans (SAHO, 2015).

${ }^{x i x}$ Informal sector are those who have small businesses like those with spaza shops, hawkers, etc.

${ }^{x x}$ MIWORC is a research organization that examines migration and its impact on the South African Labour market

${ }^{x \times i}$ Dr. Sally Peberdy is a senior researcher at the Guateng City Region Observatory.

xxii Section I of the Alien Control Legislation defined aliens as a person who is not a South African citizen.

xxiii FMSP is now regarded as African Center for Migration Studies.

xxiv Minister for Water and Sanitation 
${ }^{x x v}$ The South African immigration law has been constantly amended so as to curtail the influx of immigrants in the country. From Aliens Amendment Act of 1986; Aliens Control Act No 96 of 1991, Aliens Control Act No 76 of 1995; The Immigration Act 13 of 2002 and the Immigration Regulations of 2014

xxvi Though most times, they play into the gallery by carrying government officials and the press to those sites. After the visit of these officials, the affected citizens are mostly abandoned or displaced. While some are rearrested again and taken unjustly (see Hayem, 2013:pp 93-96) 